53. Pavese N, Napolitano A, De Iaco G, et al. Clinical outcome and magnetic resonance imaging of carbon monoxide intoxication. A long-term follow-up study. Ital J Neurol Sci 1999;20: 171-178.

54. Lee MS, Marsden CD. Neurological sequelae following carbon monoxide poisoning clinical course and outcome according to the clinical types and brain computed tomography scan findings. Mov Disord 1994;9:550-558.

55. Choi IS, Kim SK, Lee SS, Choi YC. Evaluation of outcome of delayed neurologic sequelae after carbon monoxide poisoning by technetium-99m hexamethylpropylene amine oxime brain single photon emission computed tomography. Eur Neurol 1995;35:137-142.

56. Silver DA, Cross M, Fox B, Paxton RM. Computed tomography of the brain in acute carbon monoxide poisoning. Clin Radiol 1996;51:480-483.

57. Tom T, Abedon S, Clark RI, Wong W. Neuroimaging characteristics in carbon monoxide toxicity. J Neuroimaging 1996;6: $161-166$.
58. Zagami AS, Lethlean AK, Mellick R. Delayed neurological deterioration following carbon monoxide poisoning: MRI findings. J Neurol 1993;240:113-116.

59. Yoshii F, Kozuma R, Takahashi W, Haida M, Takagi S, Shinohara Y. Magnetic resonance imaging and ${ }^{11} \mathrm{C}-\mathrm{N}$-methylspiperone/positron emission tomography studies in a patient with the interval form of carbon monoxide poisoning. J Neurol Sci 1998;160:87-91.

60. Yuh W, Crain M, Loes D, Greene G, Ryals T, Sato Y. MR imaging of cerebral ischemia: findings in the first 24 hours. AJNR 1991;12:621-629.

61. Boone KB, Miller BL, Lesser IM, et al. Neuropsychological correlates of white-matter lesions in healthy elderly subjects: a threshold effect. Arch Neurol 1992;49:549-554.

62. DeCarli CD, Murphy DGM, Tranh M, et al. The effect of white matter hyperintensity volume on brain structure, cognitive performance, and cerebral metabolism of glucose in 51 healthy adults. Neurology 1995;45:2077-2084.

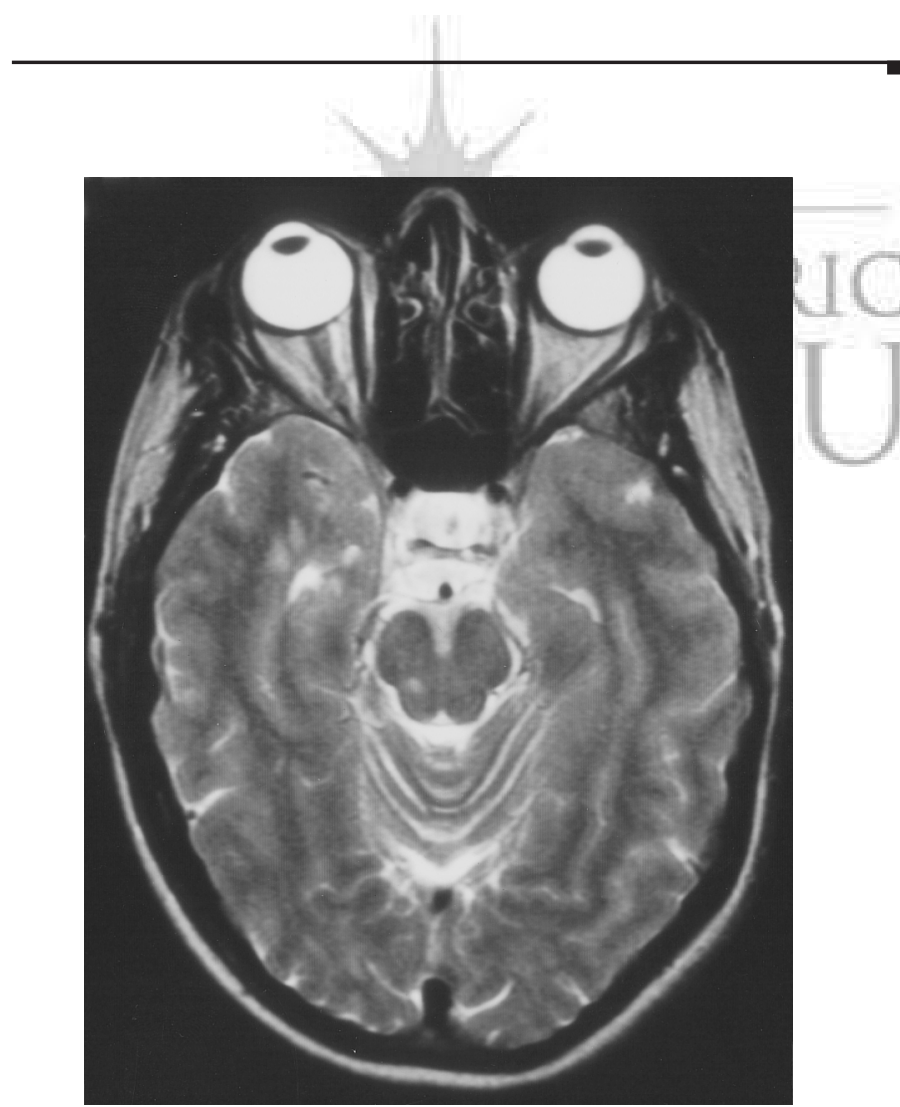

Figure. Axial T2 MRI at the level of the caudal midbrain demonstrates a hyperintense lesion at the posterolateral border of the red nucleus, close to the right third nerve fascicle. White-matter lesions around the right temporal horn, and in the occipital lobes, are also seen.
Neuro Images

\section{Painful third nerve palsy in MS}

P.I. Bentley, MRCP, T. Kimber, FRACP,

A.H.V. Schapira, MD, DSc, FmedSci,

London, United Kingdom

A 36-year-old woman presented with an acute, painful, pupil-involving third nerve palsy. She had been diagnosed with MS 5 months previously, when she had presented with a resolving myelopathy. MRI scans at that time had shown multiple white matter lesions in the brain and spinal cord consistent with demyelinating plaques. On this occasion, repeat MRI brain scan showed a new midbrain lesion adjacent to the right third nerve fascicle (figure). MRA of the circle of Willis was normal. The patient was treated with IV methylprednisolone and made a full recovery. Isolated third nerve palsy is rare in MS, ${ }^{1}$ but may mimic a posterior communicating artery aneurysm. ${ }^{2}$

1. Rush JA, Younge BR. Paralysis of cranial nerves III, IV and VI. Arch Ophthalmol 1981;99:76-79.

2. Galer BS, Lipton RB, Weinstein S, Bello L, Solomon S. Apoplectic headache and oculomotor nerve palsy: an unusual presentation of multiple sclerosis. Neurology 1990;40:1465-1466. 


\title{
Neurology
}

\author{
Painful third nerve palsy in MS
}

P.I. Bentley, T. Kimber and A.H.V. Schapira

Neurology 2002;58;1532

DOI 10.1212/WNL.58.10.1532

\section{This information is current as of May 28, 2002}

\section{Updated Information \& Services}

\section{References}

Citations

Subspecialty Collections

Permissions \& Licensing

Reprints including high resolution figures, can be found at: http://n.neurology.org/content/58/10/1532.full

This article cites 2 articles, 1 of which you can access for free at: http://n.neurology.org/content/58/10/1532.full\#ref-list-1

This article has been cited by 1 HighWire-hosted articles: http://n.neurology.org/content/58/10/1532.full\#\#otherarticles

This article, along with others on similar topics, appears in the following collection(s):

\section{MRI}

http://n.neurology.org/cgi/collection/mri

Multiple sclerosis

http://n.neurology.org/cgi/collection/multiple_sclerosis

Ocular motility

http://n.neurology.org/cgi/collection/ocular_motility

Information about reproducing this article in parts (figures,tables) or in its entirety can be found online at:

http://www.neurology.org/about/about_the_journal\#permissions

Information about ordering reprints can be found online:

http://n.neurology.org/subscribers/advertise

Neurology ${ }^{\circledR}$ is the official journal of the American Academy of Neurology. Published continuously since 1951, it is now a weekly with 48 issues per year. Copyright . All rights reserved. Print ISSN: 0028-3878.

Online ISSN: 1526-632X.

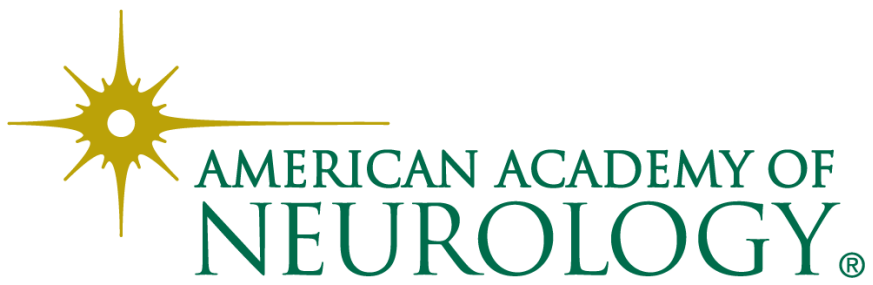

